\title{
Reproductive characteristics of lambs actively immunized early in life with inhibin-enriched preparations from follicular fluid of cows
}

\author{
S. A. R. Al-Obaidi, B. M. Bindon*, M. A. Hillard and T. O’Shea \\ Department of Physiology, University of New England, Armidale, New South Wales 2351 and \\ *Division of Animal Production, CSIRO, Armidale, New South Wales 2350, Australia
}

\begin{abstract}
Summary. Active immunization of Merino and crossbred ewe lambs early in life with a partly purified inhibin derived from bovine follicular fluid (bFF) advanced their puberty. This occurred whether the lambs were immunized from 3 weeks of age or from 9 weeks of age or just 3 times between 3 and 9 weeks. However, the effect was more obvious with multiple injections starting at 3 weeks of age. The ovulation rate of the immunized lambs was significantly higher than that of the control ewes. When lambs were subjected to multiple immunizations the increased ovulation rate persisted in Merinos for at least 1 year after immunization ceased. The lambs injected 3 times only (at 3,6 and 9 weeks of age) did not show any increase in ovulation rate. Plasma concentrations of FSH and LH measured in blood samples taken 1 week after immunization were not significantly different between the treatment groups.

Daily sperm output in the urine and testis diameter were measured in ram lambs from the same breeds and flocks as the ewe lambs. Immunization with the inhibin preparation from 3 weeks of age resulted in a significant increase in daily sperm output $\left(4255 \pm 701\right.$ vs $\left.2344 \pm 344 \times 10^{6}, P<0.01\right)$ and testis diameter $(5.21 \pm 0.3 v s$ $4.33 \pm 0.2 \mathrm{~cm}, P<0.05)$ in Merino rams examined in the non-breeding season when the rams were aged 23 months. Although the same trend was seen in the following year the differences were not significant. Immunization from 9 weeks of age had no effect. A similar increase in daily sperm output was seen (at 20 and 25 months of age) in crossbred rams immunized from 3 weeks of age but the difference was not significant. Plasma concentrations of FSH (but not $\mathrm{LH}$ ) in samples from rams immunized from 3 weeks of age were significantly higher than those of control rams at 7 and 60 weeks of age in Merino rams and at 23 and 31 weeks of age in crossbred rams. Plasma FSH concentrations at 21 and 26 weeks of age in the Merino rams immunized from 3 weeks of age were higher than those of control lambs, and these increases preceded a significant $(P<0.05)$ increase in testicular diameter at 30 weeks of age $(4.99 \pm 0.2 \mathrm{vs}$ $4 \cdot 37 \pm 0 \cdot 2 \mathrm{~cm})$.
\end{abstract}

These results suggest that active immunization early in life with an inhibin-enriched fraction from $\mathrm{bFF}$ advances puberty in ewe lambs. If there were multiple immunizations ovulation rate was also increased. Immunization from 3 weeks of age increased sperm production when the Merino lambs were first examined at 23 months of age.

\section{Introduction}

Inhibin, produced by the gonads, is a non-steroidal hormone that specifically regulates the secretion of follicle-stimulating hormone (FSH) by the pituitary gland without affecting release of luteinizing hormone (LH) (Davies et al., 1978; de Jong, 1979; Franchimont et al., 1979; Cummins et al., 1983; Robertson et al., 1985). Until the recent purification of inhibin (Robertson et al., 1985), 
reports of its functions have so far been based on the use of crude biological material such as follicular fluid (de Jong \& Sharpe, 1976) or partly purified fractions (Jansen et al., 1981).

Previous studies have shown that immunization of adult ewes with partly purified inhibin preparations derived from bovine follicular fluid results in a marked increase in ovulation rate (Cummins, 1983; Henderson et al., 1984; O'Shea et al., 1984; Cummins et al., 1986). These results provided indirect evidence for the hypothesis that inhibin is involved in the control of FSH secretion and hence follicular maturation and ovulation.

Blanc (1980) suggested that inhibin may play a role in the induction of spermatogenesis in the prepubertal male. This was supported by the immature male being more responsive to inhibin (Hermans et al., 1980; Vijayalakshmi et al., 1980). The hypothesis behind the present experiments was that immunization of sheep with an inhibin-enriched preparation would neutralize the effect of endogenous inhibin (Al-Obaidi et al., 1986), increase plasma FSH concentration and consequently advance puberty and increase ovulation rate in ewe lambs and sperm production in rams.

\section{Materials and Methods}

\section{Animals and methods}

Animals. Fine wool Merino lambs and crossbred lambs resulting from mating Merino $\times$ Border Leicester ewes with Dorset rams were used.

Preparation of partly purified inhibin. Follicular fluid was obtained from ovaries of cows as described previously (Cummins et al., 1986). The inhibin-enriched fraction ( $\left.\mathrm{PPI}_{1}\right)$ used in crossbred lambs was prepared by affinity chromatography of bFF on Matrix gel Red A (Reactive Red 120, Sigma, St Louis, MO, U.S.A.) as described previously (Cummins et al., 1986). The PPI ${ }_{2}$ used in Merino lambs was prepared by sequential chromatography on two of the affinity gels described by de Jong et al. (1981). Up to $30 \mathrm{ml}$ of the active fraction from a Matrix Red A column were loaded onto a $2.6 \mathrm{~cm}$ diameter column packed to a bed height of $7 \mathrm{~cm}$ with Sepharose-immobilized poly-(L-lysine)-deoxycholic acid gel (Pierce Chemical Co., Rockford, IL, U.S.A.), previously equilibrated with Buffer A (0.2 M-Tris at pH 8). Nonactive materials were eluted by a further $60 \mathrm{ml}$ Buffer A followed by $60 \mathrm{ml}$ Buffer B $(0.05 \mathrm{M}$-borax titrated to $\mathrm{pH} 9.5$ with $0.2 \mathrm{M}-\mathrm{NaOH}$ ). The active material, purified 66 -fold over that in the original fluid (de Jong et al., 1981), was then

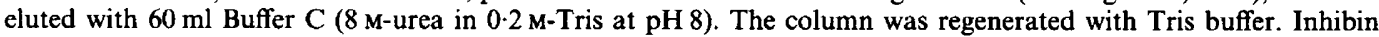
biological activity in both fractions of bFF was monitored using a bioassay based on the inhibition of hCG-induced ovulation in pregnant mice of the QS strain (Cummins et al., 1986). In this bioassay a significant $(P<0.05)$ reduction in ovulation rate was caused by $0.05 \mathrm{ml}$ bovine follicular fiuid $(50-60 \mathrm{mg}$ protein/ml), $0.1 \mathrm{ml}$ active fraction after Matrix gel Red A chromatography $(1.2-3 \mathrm{mg}$ protein $/ \mathrm{ml})$ and $0.2 \mathrm{ml}$ active fraction after deoxycholic acid gel chromatography $(0 \cdot 2-0.6 \mathrm{mg}$ protein $/ \mathrm{ml})$.

Blood sampling and hormone assays. Blood samples for FSH and LH measurements were taken hourly for $5 \mathrm{~h}$ starting at $09: 00 \mathrm{~h}$ by venepuncture into heparinized tubes 1 week after immunization and on other occasions from some lambs. The plasma was separated by centrifugation, pooled by taking equal sub-samples to form a composite sample from each lamb for each bleeding day, and stored at $-20^{\circ} \mathrm{C}$ until assayed for FSH and LH by radioimmunoassay as described previously (Al-Obaidi et al., 1986). For the FSH assay, an ovine standard FSH preparation (NIAMDDoFSH-RP-1) and ovine FSH tracer (NIAMDD-oFSH-I-1) were used: within- and between-assay coefficients of variation (CV) were less than $9 \%$ and $7 \%$ respectively, and the sensitivity of the assay was $0.25-0.5 \mathrm{ng} / \mathrm{ml}$.

Plasma LH concentration was measured using ovine LH (LER-1374.A, a gift from Dr L. E. Reichert) as tracer and NIH-LH-S16 as reference preparation. For plasma LH, within- and between-assay CVs were less than 3.5\% and $13 \%$ respectively. The sensitivity of the assay was $0 \cdot 3-0 \cdot 4 \mathrm{ng} / \mathrm{ml}$.

Plasma progesterone concentrations were measured by radioimmunoassay based on the method of Avenell et al. (1985) on samples taken at different times from the Merino ewes (at 10, 25 and 27 weeks of age) and at 8-12 days after each of the first few episodes of oestrous activity in crossbred ewes. The standard curve for progesterone was based on triplicate of serial dilution from 800 to $12.5 \mathrm{pg}$ progesterone per tube. Solvent blanks were $<10 \mathrm{pg} / \mathrm{ml}$ and a reference $100 \mu \mathrm{l}$ of wether plasma was $12.5 \mathrm{pg} / \mathrm{ml}$. Recoveries of 2 and $10 \mathrm{ng}$ progesterone added to wether plasma were 94 and $91 \%$ respectively. The present results have not been corrected for extraction losses. For a reference plasma from a ewe in the mid-luteal phase (Day 9 of the oestrous cycle), progesterone concentrations were $2.6 \mathrm{ng} / \mathrm{ml}$. The sensitivity of the assay was $12.5 \mathrm{pg} /$ assay tube or $0.125 \mathrm{ng} / \mathrm{ml}$ plasma. The within- and between-assay (4 estimates) CVs were $3.2 \%$ and $7.0 \%$ respectively.

Immunization of lambs. The sources of the immunogen were the PPI preparations described above. The immunogen mixture contained $50 \%(\mathrm{v} / \mathrm{v})$ of Freund's complete adjuvant, $0.08 \%$ Tween 80 and the PPI immunogen solution, and 
was made up to the required volume with water and emulsified. Each lamb was then injected with three equally divided doses given i.m. into each hind leg and s.c. into 4 or 5 sites along the back. The total amount of protein was $0.3 \mathrm{mg}$ for the first 2 treatments, increasing in the subsequent injections to $0.5 \mathrm{mg}$ and then to $1.0 \mathrm{mg}$ at 6 months of age until injection ceased at 35 weeks of age. Immunization was at 3-4 week intervals. Control lambs were injected similarly with an equivalent volume of Freund's complete adjuvant.

The liveweight of each lamb was recorded to the nearest $0.5 \mathrm{~kg}$ each time they were bled and at $1-2$-month intervals thereafter. Vasectomized rams fitted with harnesses and crayons were run with the ewe lambs and marks recorded at 1-2-week intervals.

\section{Experiment 1: active immunization of ewe lambs with inhibin-enriched preparations from bovine follicular fluid}

Merino ewe lambs. Lambs $(\mathrm{N}=24)$ born in October 1982 were randomized within age and birth weight classifications into 3 groups and treated as follows: Group $I_{3}(N=9)$ received 9 injections of $0.3-1 \cdot 0 \mathrm{mg} \mathrm{PPI}{ }_{2}$ protein during 3-35 weeks of age; Group $I_{9}(N=6)$ received 7 injections of $0.5-1.0 \mathrm{mg} \mathrm{PPI}{ }_{2}$ protein during 9-35 weeks of age; and Group $\mathrm{C}(\mathrm{N}=9)$ received 9 injections of Freund's complete adjuvant during 3-35 weeks of age. Ovarian examination by laparoscopy was carried out at approximately monthly intervals between 28 and 87 weeks of age (April 1983 to June 1984).

Crossbred ewe lambs. Lambs $(\mathrm{N}=64)$ born in September 1983 were randomized within age, litter size and birth weight classifications for this experiment. They were allocated to 3 treatment groups and treated as follows: Group $V_{3}$ $(\mathrm{N}=21)$ received 9 injections of $0.3-1.0 \mathrm{mg}$ PPI 1 protein during 3-35 weeks of age; Group $\mathrm{V}_{9}(\mathrm{~N}=21)$ received injections of $0.3,0.3$ and $0.5 \mathrm{mg} \mathrm{PPI}{ }_{1}$ protein at 3,6 and 9 weeks of age respectively plus 6 injections of Freund's complete adjuvant until 35 weeks of age; and Group $\mathrm{C}(\mathrm{N}=22)$ received 9 injections of Freund's complete adjuvant during 3-35 weeks of age.

To accommodate the larger number of animals, the lambs within each treatment group were randomly allocated to be bled alternately from 3 weeks of age and then as described above from 7 weeks of age, so that some group means in the results are at times other than 1 week after an immunization.

Laparoscopy was carried out at 10 weeks of age on the heaviest 10 lambs in each group. Laparoscopic ovarian examinations were then performed thereafter until 86 weeks of age (May 1985) at the ages given in Table 2.

\section{Experiment 2: active immunization of rams early in life with inhibin-enriched preparations from bovine follicular fluid}

Merino ram lambs. Lambs $(\mathrm{N}=26)$ born in October 1982 were randomized within age and birth weight classification into 3 groups $\left(I_{3}, N=8 ; I_{9}, N=8\right.$; and $\left.C, N=10\right)$. The preparation of immunogen, immunization procedures and bleeding schedule were similar to those used for the ewe lambs of the same flock as described in Exp. 1(a). One additional blood sampling was carried at at $\sim 20$ months of age.

Testis diameter, the difference between the largest diameter of each testis plus scrotal skin and the thickness of a fold of skin, was measured with callipers to the nearest $0.01 \mathrm{~cm}$ at the same time as the live weight was recorded and before slaughter. The mean diameter of left and right testis was defined as testis diameter. All measurements were carried out by one operator.

The mean daily output of spermatozoa in the urine was measured at 23 months of age (non-breeding season of 1984), at 31 months of age (breeding season of 1985) and at 35 months of age (non-breeding season of 1985) as described by Lino et al. (1967). Each ram was placed in a metabolism cage, and urine was collected in preservative via a flexible cone (Dick \& Mules, 1954) strapped to the abdomen for 11 and 9 consecutive days during 1984 and 1985 respectively. The urine volume of each day was recorded, a $5 \mathrm{ml}$ sample of urine was taken and the number of spermatozoa present was estimated by the use of a haemocytometer.

At 43 months of age (breeding season, May 1986) 15 rams ( 5 of each treatment group) were randomly selected. They were weighed, the testis diameter was recorded and they were then slaughtered. Both testes were removed intact. The epididymis was dissected from each testis and individually weighed to the nearest $0.5 \mathrm{~g}$. Each testis was individually weighed after removing excess connective tissue and trimming off the pampiniform plexus. The mean weights of left and right epididymides and testes are referred to as epididymal weight and testis weight.

Crossbred ram lambs. Lambs $(\mathrm{N}=61)$ born in September 1983 were allocated randomly to 3 treatment groups $\left(\mathrm{V}_{3}, \mathrm{~N}=21 ; \mathrm{V}_{9}, \mathrm{~N}=20\right.$; and $\left.\mathrm{C}, \mathrm{N}=21\right)$. The preparation of immunogen, immunization procedures and bleeding schedule were similar to those used for the ewe lambs of the same flock described in Exp. 1(b). Testis diameter was recorded as described in Exp. 2(a).

For daily sperm output measurements, urine samples were collected, as described above, for 9 consecutive days from 8 rams selected randomly from each of Groups $C$ and $V_{3}$ and 20 months of age (breeding season of 1985) and at 25 months of age (non-breeding season of 1985). At 32 months of age (breeding season, May 1985) 10 rams (5 from Group $\mathrm{C}$ and 5 from Group $\mathrm{I}_{3}$ ) were randomly selected from these rams. The values indicated for Exp. 2(a) were recorded as described above. Daily sperm output was determined on the remaining 16 and 10 rams in Groups $\mathrm{C}$ and $\mathrm{V}_{3}$ respectively at 37 months of age (non-breeding season 1986). 


\section{Statistical analysis}

Values presented are mean \pm s.e.m. and data were examined by means of analysis of variance and covariance with repeated measures, $\chi^{2}$ and $t$ tests, comparing treated animals with the control group. Statistical significance of ovulation rate was not tested at times when none or only one Group C lamb had ovulated. Within each breed type simple linear correlation coefficients $(r)$ were calculated between the various testicular parameters and live weight at slaughter of all rams regardless of their treatment.

\section{Results}

Interpretation of the plasma FSH and LH concentration data was not altered by use of the $\log _{e}$ (ng $+1 / \mathrm{ml}$ ) transformation sometimes suggested for this type of data, and so untransformed results are presented.

\section{Experiment $1(a)$}

Immunization of Merino ewe lambs with $\mathrm{PPI}_{2}$ resulted in an advancement of puberty (Fig. 1). Ovarian examination of lambs at 28 weeks of age revealed that $1 / 9$ Group $C$ lambs had 1 corpus albicans, whereas $6 / 9$ Group $I_{3}$ and $4 / 6 \mathrm{Group}_{9}$ lambs had up to 8 recent ovulations. The difference in number of lambs ovulating was significant $\left(\chi^{2}=5.74, P<0.025\right.$ and $\chi^{2}=4.61, P<0.05$ for Groups $I_{3}$ and $I_{9}$ respectively compared with Group $C$ ). The ovulation rate was high in Group $I_{3}$ and $I_{9}$ lambs that had ovulated $(2.67 \pm 0.92$ and $3.25 \pm 1.60$ respectively). Progesterone $(>0.3 \mathrm{ng} / \mathrm{ml})$ was detected in only 1 Group $C$ lamb and in $9 / 15$ immunized lambs within 14 days of the first laparoscopy, indicating that the $\mathrm{CL}$ were functional. In terms of the proportion of lambs showing behavioural oestrus (as shown in Fig. 1), the difference between Groups $\mathrm{I}_{3}$ and $\mathrm{C}$ was significant $\left(\chi^{2}=6.77, P<0.01\right)$ at 28 weeks of age. The $1 \mathrm{C}$ lamb that ovulated did not show oestrus and only $1 / 4$ lambs in Group $I_{9}$ which ovulated showed oestrus.

At 31 weeks of age, 6 lambs of Group $I_{3}$ showed oestrus $\left(\chi^{2}=5.84, P<0.025\right)$ and ovulated $(P<0.025)$ whereas only 1 lamb in Group $C$ and 2 in Group $I_{9}$ showed oestrus and ovulated. One Group $I_{9}$ lamb had 8 ovulations at 41 weeks of age. The differences in ovulation rate between lambs in Groups $\mathrm{C}$ and $\mathrm{I}_{3}$ were significant $(P<0.05)$ at 56 and 66 weeks of age (Table 1). At 11 months after the last immunization, ovulation rate was significantly $(P<0.05$ at 79 and $P<0.025$ at 83 weeks of age) higher in lambs in Group $\mathrm{I}_{9}$ than in Group C. In Group $\mathrm{I}_{3}$ lambs at 79 and 83 weeks of age ovulation rate was high but the differences from Group $\mathrm{C}$ were not significant.

The overall mean live weight of the Group $\mathrm{I}_{3}$ lambs was not significantly different from that in Groups $C$ and $I_{9}$. The 2 Group $C$ lambs that ovulated at 28 and 31 weeks of age had live weights of 31.8 and $27.5 \mathrm{~kg}$, and at the same age values were $28.0 \pm 0.9 \mathrm{~kg}$ and $25.5 \pm 0.7 \mathrm{~kg}$ for the 7 Group $I_{3}$ and 4 Group $I_{9}$ lambs that ovulated. These values were not significantly different.

Table 1 shows the ovulation data for each group in the 12 successive laparoscopies. The $\mathrm{PPI}_{2^{-}}$ immunized lambs (Groups $\mathrm{I}_{3}$ and $\mathrm{I}_{9}$ ) had significantly higher within-lamb mean ovulation rate than did the Group $C$ lambs. The response to $\mathrm{PPI}_{2}$ was also shown by the fact that 5 lambs of Group $I_{3}$ and 3 of Group $I_{9}$ had up to $9 \mathrm{CL}$, while in Group $C$ the maximum of $3 \mathrm{CL}$ occurred once only.

At 28 and 31 weeks of age, it appeared that the $\mathrm{PPI}_{2}$-immunized lambs were showing a higher degree of follicular development, although the difference was not significant. These lambs had a mean of $0 \cdot 14$ small follicles ( $<5 \mathrm{~mm}$ diameter), $2 \cdot 3$ medium follicles ( $5 \mathrm{~mm}$ diameter) and 0.2 large follicles ( $>5 \mathrm{~mm}$ diameter) compared with 0.4 small, 0.8 medium and 0.3 large follicles in Group C.

On none of the 9 occasions at which blood samples were obtained was there a significant difference in plasma concentrations of FSH or LH between the lambs in Group C and those immunized with $\mathrm{PPI}_{2}$ (Groups $\mathrm{I}_{3}$ and $\mathrm{I}_{9}$ ). 


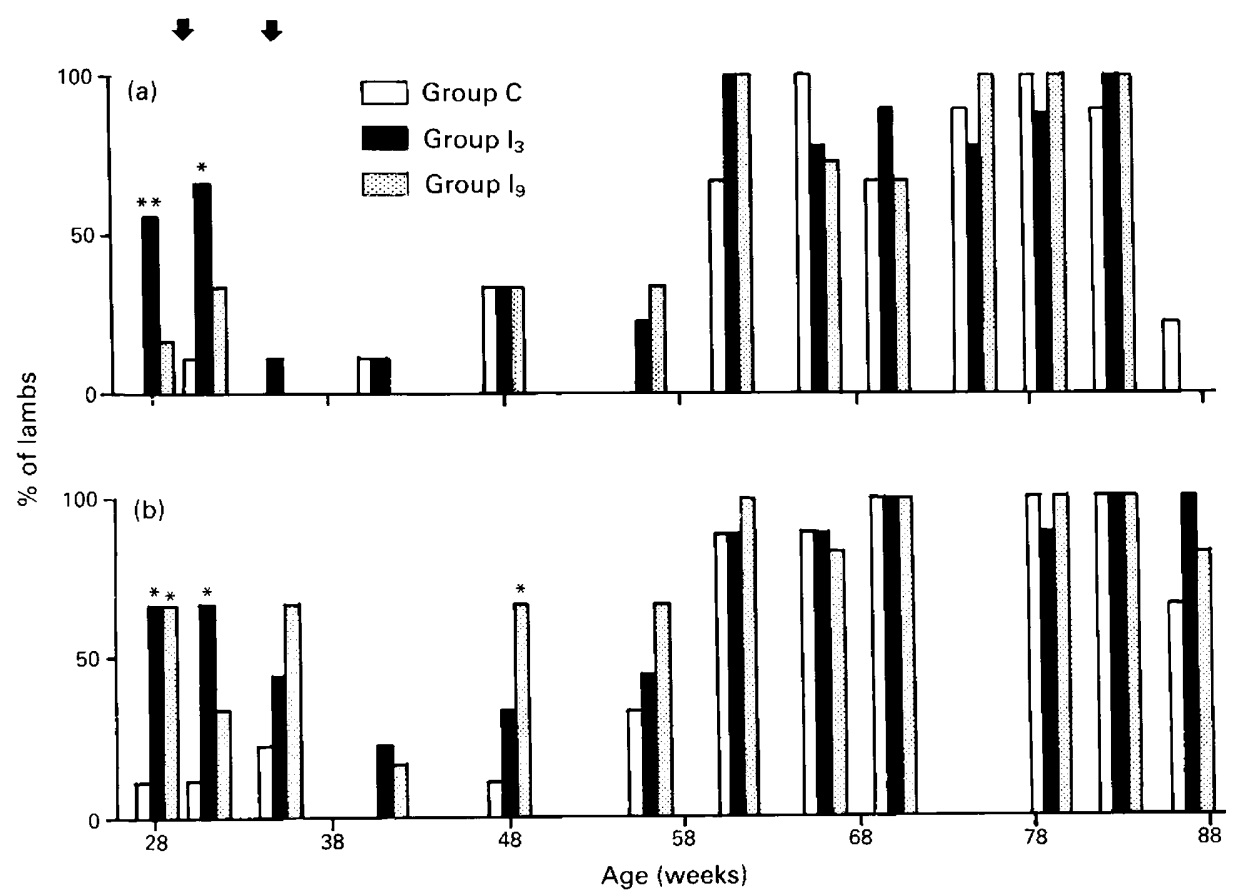

Fig. 1. Occurrence of behavioural oestrus (a) and ovulation (b) in Merino ewe lambs (Exp. 1a) immunized with an inhibin-enriched fraction from bovine follicular fluid ( $\boldsymbol{\square}$, Group $\mathrm{I}_{3}, 3-35$ weeks, $N=9$; 13 , Group $I_{9}, 9-35$ weeks, $N=6$ ), or injected with Freund's adjuvant $([]$, Group $\mathrm{C}, \mathrm{N}=9$ ). Arrows indicate dates of last two immunizations. ${ }^{*} P<0.05,{ }^{* *} P<0.01$.

Table 1. Number of corpora lutea (CL) of control (Group C) and inhibin-immunized (Groups $I_{3} \& I_{9}$ ) Merino ewe lambs at different ages and mean \pm s.e.m. of the within-lamb ovulation rate (Exp. la)

\begin{tabular}{|c|c|c|c|c|c|c|c|c|c|c|c|c|c|c|}
\hline \multirow[b]{2}{*}{ Group } & \multirow[b]{2}{*}{$\mathrm{N}$} & \multicolumn{12}{|c|}{ No. of CL at different ages (weeks) } & \multirow{2}{*}{$\begin{array}{l}\text { Ovulation } \\
\text { rate }\end{array}$} \\
\hline & & 28 & 31 & 35 & 41 & 48 & 56 & 61 & 66 & 70 & 79 & 83 & 87 & \\
\hline $\mathrm{C}$ & 9 & $\begin{array}{c}1 \\
(1)\end{array}$ & $\begin{array}{c}1 \\
(1)\end{array}$ & $\begin{array}{c}3 \\
(2)\end{array}$ & $\begin{array}{c}0 \\
(0)\end{array}$ & $\begin{array}{c}2 \\
(1)\end{array}$ & $\begin{array}{c}3 \\
(3)\end{array}$ & $\begin{array}{c}9 \\
(8)\end{array}$ & $\begin{array}{c}8 \\
(8)\end{array}$ & $\begin{array}{l}10 \\
\text { (9) }\end{array}$ & $\begin{array}{c}9 \\
(9)\end{array}$ & $\begin{array}{l}12 \\
(9)\end{array}$ & $\begin{array}{c}7 \\
(6)\end{array}$ & $1 \cdot 11 \pm 0.07$ \\
\hline $\mathbf{I}_{3}$ & 9 & $\begin{array}{l}16 \\
(6)\end{array}$ & $\begin{array}{l}20 \\
(6)\end{array}$ & $\begin{array}{c}9 \\
(4)\end{array}$ & $\begin{array}{c}4 \\
(2)\end{array}$ & $\begin{array}{c}9 \\
(3)\end{array}$ & $\begin{array}{c}8 \\
(4)\end{array}$ & $\begin{array}{l}15 \\
(8)\end{array}$ & $\begin{array}{l}15 \\
(8)\end{array}$ & $\begin{array}{l}18 \\
\text { (9) }\end{array}$ & $\begin{array}{l}16 \\
(8)\end{array}$ & $\begin{array}{l}30 \\
(9)\end{array}$ & $\begin{array}{l}24 \\
(9)\end{array}$ & $2 \cdot 24 \pm 0 \cdot 38^{* *}$ \\
\hline $\mathbf{I}_{9}$ & 6 & $\begin{array}{l}13 \\
(4)\end{array}$ & $\begin{array}{c}7 \\
(2)\end{array}$ & $\begin{array}{l}14 \\
(4)\end{array}$ & $\begin{array}{c}8 \\
(1)\end{array}$ & $\begin{array}{c}5 \\
(4)\end{array}$ & $\begin{array}{c}4 \\
(4)\end{array}$ & $\begin{array}{l}12 \\
(6)\end{array}$ & $\begin{array}{l}10 \\
(5)\end{array}$ & $\begin{array}{l}13 \\
\text { (6) }\end{array}$ & $\begin{array}{l}16 \\
(6)\end{array}$ & $\begin{array}{l}25 \\
(6)\end{array}$ & $\begin{array}{l}10 \\
(5)\end{array}$ & $2.43 \pm 0.62^{*}$ \\
\hline
\end{tabular}

Values in parentheses are the no. of lambs that ovulated.

*Significantly higher than for Group C lambs, $P<0.025$.

**Significantly higher than for Group C lambs, $P<0.01$.

\section{Experiment 1(b)}

Immunization with PPI 1 significantly $(P<0.025)$ decreased the age (days) at which oestrus was first detected ( $305 \pm 28$ in Group $V_{3}, 305 \pm 29$ in Group $V_{9}$ and $409 \pm 34$ in Group $C$ lambs). The number of lambs showing behavioural oestrus at least once during their first breeding season in 1984 was significantly $\left(\chi^{2}=5.795, P<0.025\right)$ higher in Groups $V_{3}$ and $V_{9}$ (each 17/21) lambs 

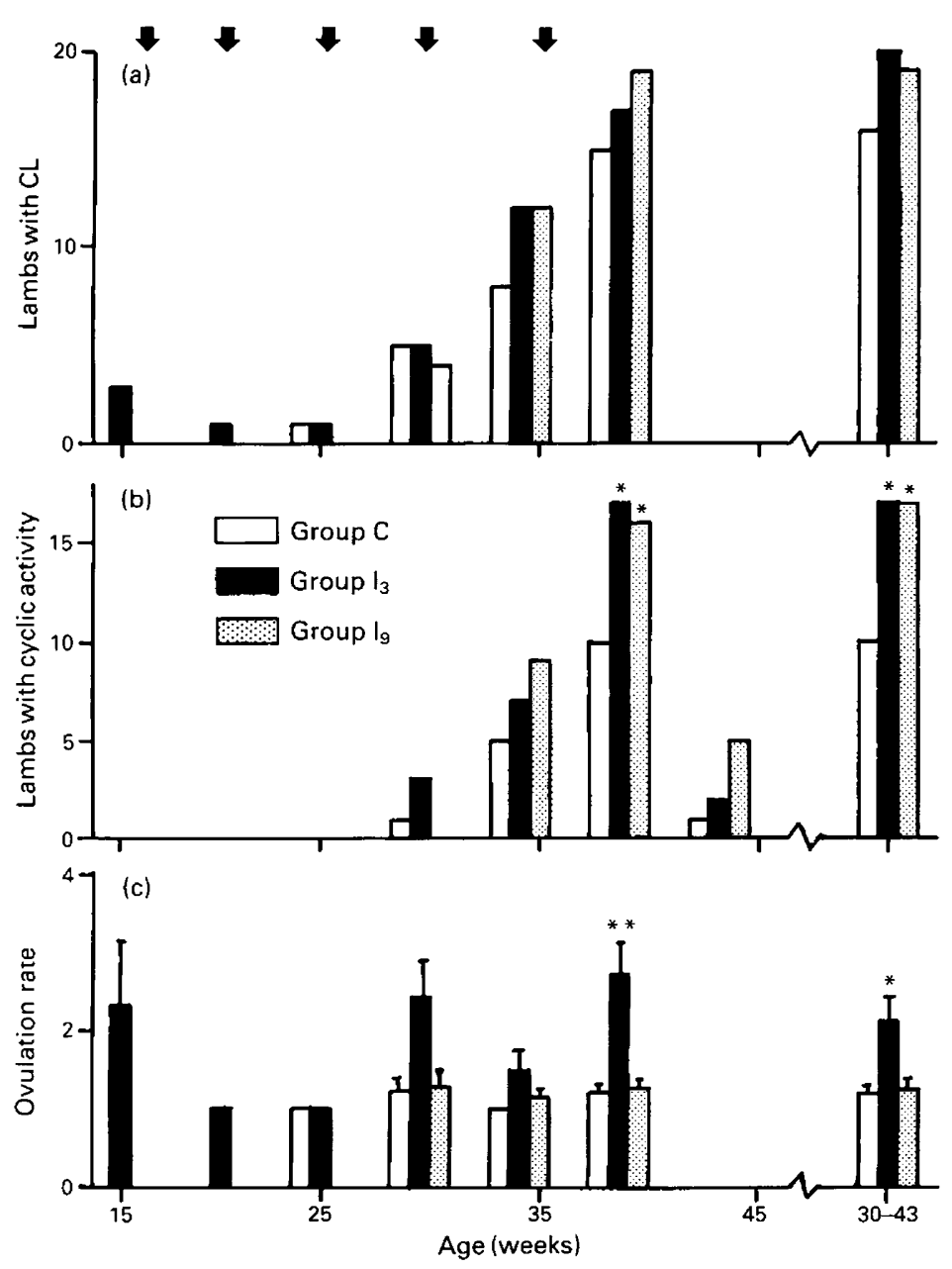

Fig. 2. Number of lambs with a CL (a), number showing cyclic activity, i.e. behavioural oestrus followed by a functional CL (b), and ovulation rate of lambs that ovulated (c), in crossbred ewe lambs (Exp. 1b) immunized with an inhibin-enriched fraction from bovine follicular fluid ( $\boldsymbol{\square}$, Group $V_{3}, 3-35$ weeks; $:$, Group $V_{9}, 3-9$ weeks), or injected with Freund's adjuvant ( $\square$, Group $C$ ). $N=20-22$. Arrows indicate dates of last 5 immunizations. ${ }^{*} P<0.025,{ }^{* *} P<0.01$.

compared with Group C (10/22). The number of lambs with cyclic activity (behavioural oestrus with a subsequent functional $C L$ producing progesterone) was greater $(P<0.05)$ in May in Groups $V_{3}(17 / 21)$ and $V_{9}(16 / 20)$ than in Group C (10/21), and was higher also over the total 1984 breeding season (Fig. 2).

Ovulation rate (Table 2 and Fig. 2) was significantly increased in Group $V_{3}$ lambs compared with those in Group $C$ at 38 and 82 weeks of age $(P<0.01$ and $P<0.05$ respectively). However, ovulation rate did not change in Group $V_{9}$ lambs. The response of ovulation rate to PPI immunization could also be seen in that Group $V_{3}$ lambs had significantly higher within-lamb mean ovulation rate than did Group $\mathrm{C}$ lambs whether this was determined over the first breeding season (Fig. 2; $2 \cdot 13 \pm 0 \cdot 31$ vs $1 \cdot 19 \pm 0.09$ ) or up to 86 weeks of age (Table 2). Ovulations of 3 or more (3-7 CL) occurred in 13 lambs of Group $V_{3}$ compared with a maximum of 3 ovulations 
observed in only 2 lambs in Group C and 1 lamb in Group $V_{9}$. Progesterone concentrations in plasma samples collected 8-12 days after behavioural oestrus were significantly $(r=+0.58, P<0.05)$ correlated with ovulation rate in Group $\mathrm{V}_{3}$ (ovulation rate $=-2 \cdot 18+1 \cdot 33 \mathrm{ng}$ progesterone $/ \mathrm{ml}$ plasma).

Plasma FSH and LH concentrations did not differ between the 3 groups at any of the 5 sampling times between 3 and 36 weeks of age. No differences were seen in the live weights of the three groups of lambs.

Table 2. Number of corpora lutea (CL) of control (Group C) and inhibin-immunized (Groups $\mathrm{V}_{3} \& \mathrm{~V}_{9}$ ) crossbred ewe lambs at different ages and mean \pm s.e.m. of the within-lamb ovulation rate (Exp. 1b)

\begin{tabular}{|c|c|c|c|c|c|c|c|c|c|c|c|c|c|}
\hline \multirow{2}{*}{\multicolumn{2}{|c|}{ Group }} & \multicolumn{11}{|c|}{ Age (weeks) } & \multirow{2}{*}{$\begin{array}{l}\text { Ovulation } \\
\text { rate }\end{array}$} \\
\hline & & 15 & 21 & 25 & 30 & 34 & 38 & 43 & 61 & 71 & 82 & 86 & \\
\hline \multirow[t]{3}{*}{$\mathrm{C}$} & Total CL & 0 & 0 & 1 & 6 & 8 & 18 & 0 & 0 & 8 & 30 & 36 & $1.37 \pm 0.06$ \\
\hline & ovulated & 0 & 0 & 1 & 5 & 8 & 15 & 0 & 0 & 8 & 21 & 20 & \\
\hline & No. of lambs & 22 & 22 & 22 & 22 & 22 & 22 & 21 & 21 & 21 & 21 & 21 & \\
\hline \multirow[t]{3}{*}{$v_{3}$} & Total CL & 7 & 1 & 1 & 12 & 18 & 46 & 0 & 0 & 10 & 33 & 36 & $1.93 \pm 0.12^{*}$ \\
\hline & $\begin{array}{l}\text { ovulated } \\
\text { of }\end{array}$ & 3 & 1 & 1 & 5 & 12 & 17 & 0 & 0 & 9 & 19 & 18 & \\
\hline & No. of lambs & 21 & 21 & 21 & 21 & 21 & 21 & 20 & 20 & 19 & 19 & 19 & \\
\hline \multirow[t]{3}{*}{$\mathrm{V}_{9}$} & Total CL & 0 & 0 & 0 & 5 & 14 & 24 & 0 & 0 & 5 & 26 & 37 & $1.48 \pm 0.06$ \\
\hline & $\begin{array}{l}\text { No. of lambs that } \\
\text { ovulated }\end{array}$ & 0 & 0 & 0 & 4 & 12 & 19 & 0 & 0 & 4 & 17 & 19 & \\
\hline & No. of lambs & 21 & 21 & 21 & 21 & 21 & 21 & 19 & 20 & 20 & 19 & 20 & \\
\hline
\end{tabular}

*Significantly higher than for Group C lambs, $P<0.05$.

\section{Experiment 2(a)}

The treatments had no effect on live weight at any stage during the experimental period. The epididymal weight was significantly $(r=+0.632, P<0.05)$ correlated with testis diameter and with testis weight $(r=+0.732, P<0.01)$. Testis diameter was significantly $(r=+0.881, P<0.01)$ correlated with testis weight. The testicular measures were not correlated with liveweight.

A progressive increase in testis diameter occurred in each treatment group during the first 30 weeks of age (Fig. 3). From 30 weeks until 148 weeks of age testis diameter of Group $\mathrm{I}_{3}$ rams was consistently greater than that of Group $\mathrm{C}$ rams although this difference was significant only at 30 and 98 weeks.

At 7 weeks of age, 1 week after the second immunization, plasma FSH concentration in Group $\mathrm{I}_{3}$ rams was greater $(P<0.05)$ compared with that of Group $C \operatorname{rams}(1.34 \pm 0.21 v s 0.79 \pm 0.11 \mathrm{ng} / \mathrm{ml})$. FSH concentrations in all groups fell to low values at 13 weeks after which values for Group $\mathrm{I}_{3}$ group were consistently greater than those for Group $C$. This difference was significant at 60 weeks of age. At 21 and 26 weeks more $(P<0.025)$ Group $I_{3}$ lambs had FSH plasma concentrations $>0.5 \mathrm{ng} / \mathrm{ml}$ than did Group C rams (5/8 vs $1 / 10$ and $4 / 8$ vs $0 / 10$ respectively). The FSH concentration in Group $I_{9}$ rams was not significantly different from that of Group $C$ at any time. Immunization with $\mathrm{PPI}_{2}$ had little effect on plasma $\mathbf{L H}$ concentrations (data not shown), with all treatment groups showing similar secular falls after Week 10, although mean concentration at 35 weeks of age was significantly $(P<0.05)$ lower in Group $I_{9}(1.50 \pm 0.09 \mathrm{ng} / \mathrm{ml})$ compared with Group C $(2 \cdot 11 \pm 0 \cdot 25 \mathrm{ng} / \mathrm{ml})$ rams.

The mean numbers of spermatozoa shed into the urine for rams in each of the three treatment 

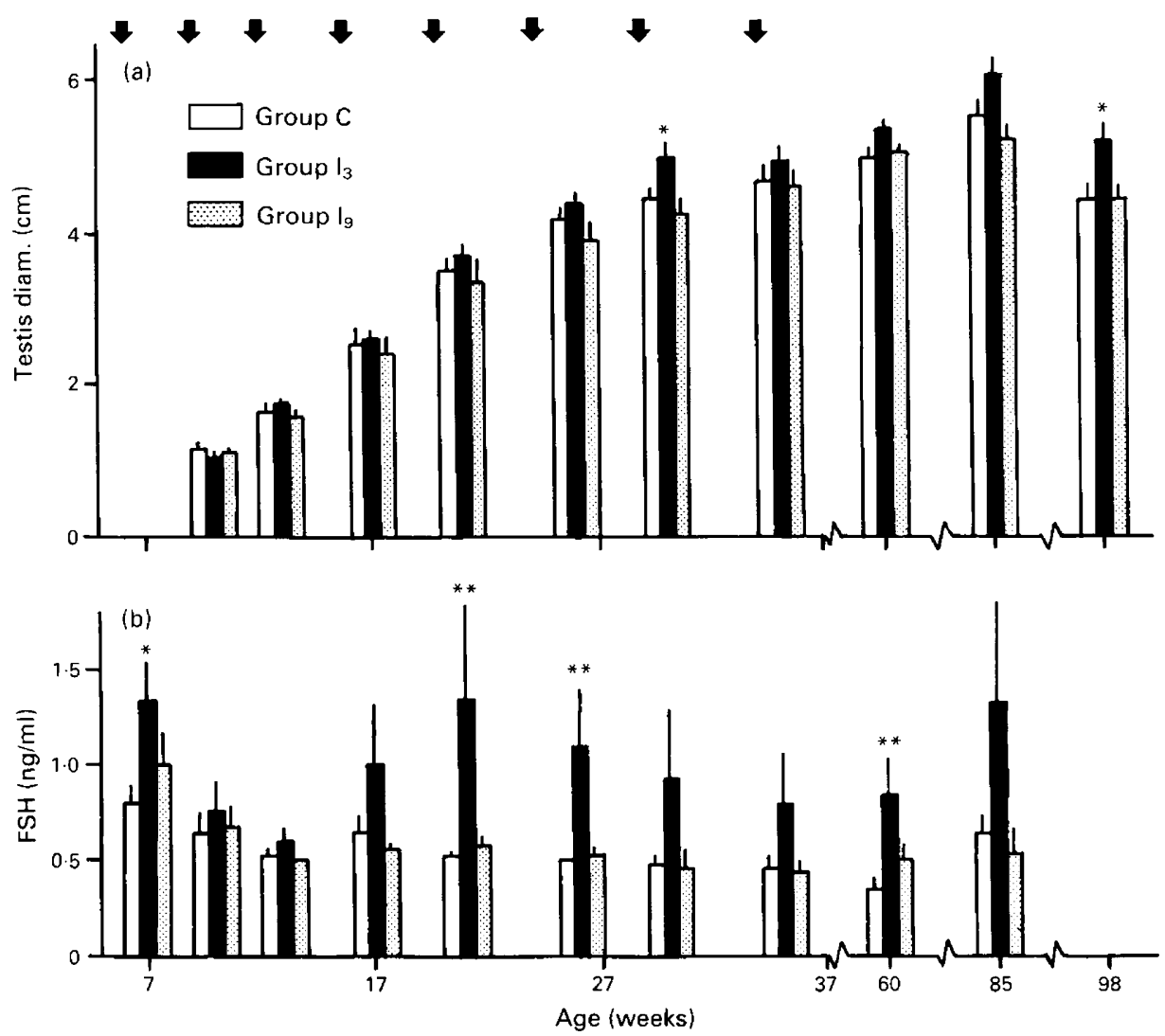

Fig. 3. Testis diameter (a) and plasma FSH concentration (b) of Merino ram lambs (Exp. 2a) immunized with an inhibin-enriched fraction from bovine follicular fluid ( $\boldsymbol{Q}$, Group $I_{3}, 3-35$ weeks; ${ }^{-}$, Group $I_{9}, 9-35$ weeks), or injected with Freund's adjuvant ( $\square$, Group $C$ ). Values are means \pm s.e.m. for $7-10$ rams. Arrows indicate dates of immunization. ${ }^{*} P<0.05$, ${ }^{* *} P<0.025$.

Table 3. Liveweight, testis diameter and daily sperm output in urine of Merino rams (Exp. 2a) immunized with an inhibin-enriched preparation from bovine follicular fluid (Groups $\mathrm{I}_{3} \& \mathrm{I}_{9}$ ) or injected with Freund's complete adjuvant (Group C)

\begin{tabular}{lccccc}
\hline $\begin{array}{l}\text { Date of } \\
\text { collection }\end{array}$ & $\begin{array}{c}\text { Age } \\
\text { (month) }\end{array}$ & $\begin{array}{c}\text { Treatment } \\
\text { group }\end{array}$ & $\begin{array}{c}\text { Live } \\
\text { weight } \\
(\mathrm{kg})\end{array}$ & $\begin{array}{c}\text { Testis } \\
\text { diameter } \\
(\mathrm{cm})\end{array}$ & $\begin{array}{c}\text { Daily sperm } \\
\text { output } \\
\left(\times 10^{-6}\right)\end{array}$ \\
\hline August & 23 & $\mathrm{C}$ & $48 \cdot 5 \pm 2 \cdot 1$ & $4 \cdot 33 \pm 0 \cdot 2$ & $2344 \pm 344$ \\
1984 & & $\mathrm{I}_{3}$ & $49 \cdot 8 \pm 1 \cdot 3$ & $5 \cdot 21 \pm 0 \cdot 3^{*}$ & $4255 \pm 701^{* *}$ \\
& & $\mathrm{I}_{9}$ & $46 \cdot 6 \pm 2 \cdot 9$ & $4 \cdot 41 \pm 0 \cdot 2$ & $2465 \pm 205$ \\
March & 31 & $\mathrm{C}$ & $57 \cdot 0 \pm 2 \cdot 1$ & $5 \cdot 13 \pm 0 \cdot 2$ & $3699 \pm 742$ \\
1985 & & $\mathrm{I}_{3}$ & $56 \cdot 3 \pm 1 \cdot 6$ & $5 \cdot 67 \pm 0 \cdot 2$ & $4588 \pm 978$ \\
& & $\mathrm{I}_{9}$ & $55 \cdot 5 \pm 2 \cdot 2$ & $5 \cdot 13 \pm 0 \cdot 1$ & $4738 \pm 881$ \\
August & 35 & $\mathrm{C}$ & $56.9 \pm 2 \cdot 3$ & $5 \cdot 76 \pm 0 \cdot 3$ & $4717 \pm 803$ \\
1985 & & $\mathrm{I}_{3}$ & $55 \cdot 9 \pm 1 \cdot 5$ & $6 \cdot 03 \pm 0 \cdot 3$ & $5297 \pm 1477$ \\
& & $\mathrm{I}_{9}$ & $57 \cdot 0 \pm 2 \cdot 0$ & $5 \cdot 53 \pm 0 \cdot 1$ & $4084 \pm 962$ \\
\hline
\end{tabular}

Values are means \pm s.e.m. for $7 \mathrm{rams} /$ group.

${ }^{*} P<0.05$ compared with Group $C$ rams.

${ }^{* *} P<0.01$ compared with Group $C$ rams. 
groups are given in Table 3. Immunization of rams with $\mathrm{PPI}_{2}$ early in life significantly increased

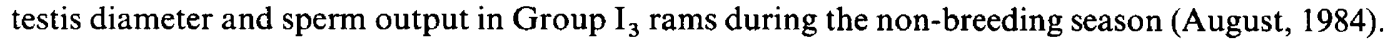
There was no significant interaction between treatment group and day of collection for sperm output in the urine during each of the 3 observation periods, indicating consistent treatment effects over time during each trial.

\section{Experiment 2(b)}

As in Merino rams, the treatment had no effect on live weight at any stage and a similar progressive increase in testis diameter occurred in each group during the first 30-33 weeks of age. However, there were no significant differences between the three treatment groups in average testis diameter at any time during the course of this study (Fig. 4).

Plasma FSH concentration, compared with that of the Group Clambs, was significantly greater in Group $\mathrm{V}_{3}$ lambs at 23 and 31 weeks of age (Fig. 4). There were no differences in FSH concentration between lambs in Groups $V_{9}$ and $C$. There were no effects of PPI 1 on plasma LH concentrations

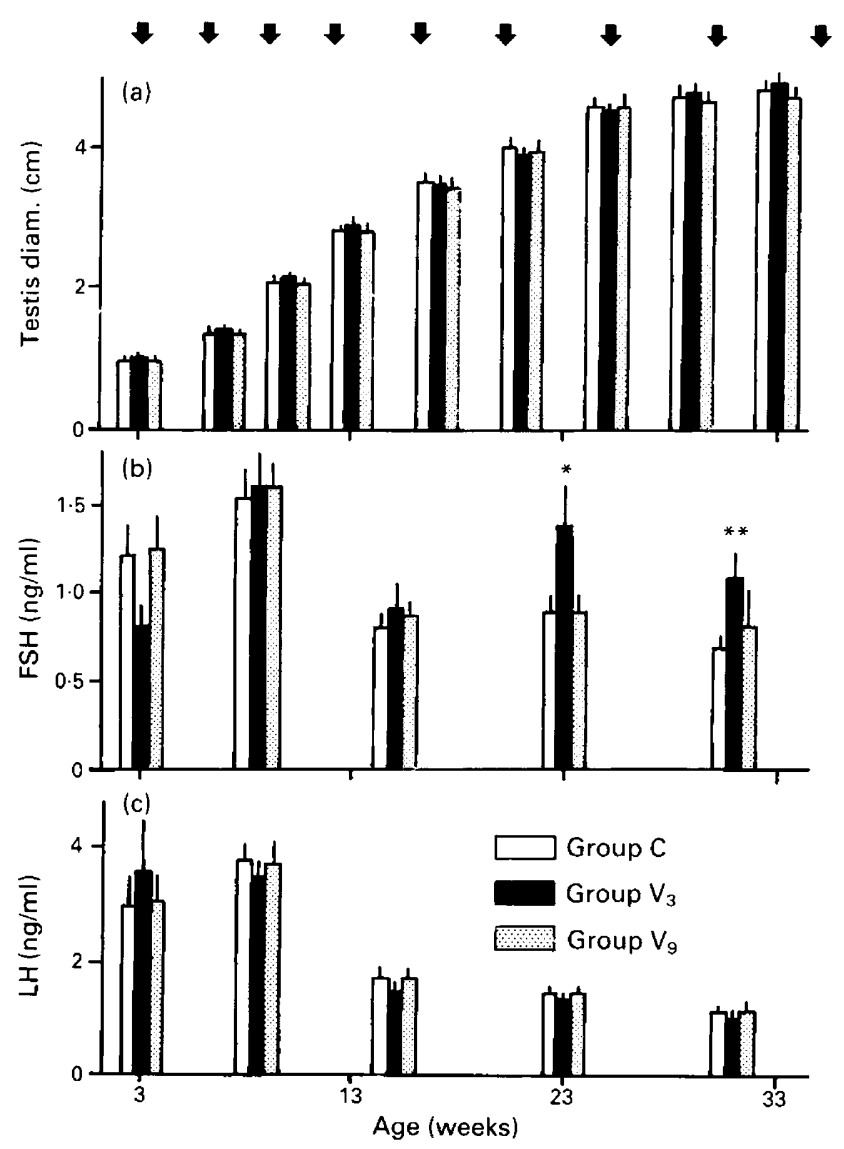

Fig. 4. Testis diameter (a), plasma FSH concentration (b), and plasma LH concentration (c), of crossbred ram lambs (Exp. 2b) immunized with an inhibin-enriched fraction from bovine follicular fluid ( $\square$, Group $V_{3}, 3-35$ weeks; 图, Group $V_{9}, 3-9$ weeks), or injected with Freund's adjuvant $(\square$, Group $C)$. Values are means \pm s.e.m. for 19-21 animals. Arrows indicate the dates of immunization. ${ }^{*} P<0.05,{ }^{* *} P<0.025$. 
(Fig. 4). A similar pattern of changes in all three groups occurred in plasma LH during this study, with high values at 3-8 weeks of age.

Although daily sperm output was $27 \%$ and $53 \%$ higher in rams immunized early in their life (Group $\mathrm{V}_{3}, \mathrm{~N}=8,5094 \pm 991$ and $4290 \pm 605 \times 10^{6}$ ) compared with those in Group $\mathrm{C}(\mathrm{N}=8$, $4009+898$ and $2809 \pm 605 \times 10^{6}$ ) during the breeding (May 1985) and non-breeding (September $1985)$ seasons respectively, the difference only approached significance $(P=0.09)$ in the nonbreeding season at 25 months of age. In the determinations done at 37 months of age there were no differences between Groups $\mathrm{C}$ and $\mathrm{V}_{3}$ in live weight $(67.6 \pm 1.9 \mathrm{vs} 66.2 \pm 1.9 \mathrm{~kg})$, testis diameter $(5.52 \pm 0.17$ vs $5.26 \pm 0.15 \mathrm{~cm})$, dialy sperm output $\left(4060 \pm 607 \times 10^{6}\right.$ vs $\left.4019 \pm 801 \times 10^{6}\right)$ or plasma FSH concentration $(0.58 \pm 0.06$ vs $0.46 \pm 0.05 \mathrm{ng} / \mathrm{ml})$.

As in Merino rams (Exp. 2a), there was no correlation between live weight and the three testicular measures. All three testicular measures were significantly correlated with each other $(r=+0.939$, $P<0.0$ I for testis diameter and weight; $r=+0.744, P<0.05$ for testis diameter and epididymal weight; and $r=+0.805, P<0.01$ for testis and epididymal weights).

\section{Discussion}

It is clear that active immunization of young ewe lambs with steroid-free partly purified inhibin obtained from follicular fluid of cows can modify the maturation of the gonads, adenohypophysis and hypothalamus and alter the protracted interplay between the negative and positive feedback effects on gonadotrophin secretion. This was reflected by a substantial advancement of puberty in immunized female lambs. At 6 months of age (Exp. la) $78 \%$ of Group $I_{3}$ lambs and $33 \%$ of Group $\mathrm{I}_{9}$ lambs showed oestrus activity while only $11 \%$ of the control lambs exhibited oestrus. This figure is much higher than that reported for Merinos by Bindon et al. (1982) who concluded that the usual pattern in this environment was for $<10 \%$ of Merino ewe lambs to cycle in the first year of life.

There have been no reports in the literature concerning inhibin and its relation to puberty in sheep apart from the speculative remarks by Blanc (1980). One possible mechanism is that immunization caused development of antibodies (Cummins et al., 1986) which altered the inhibin feedback and thus modified gonadotrophin secretion. Although in a previous study with adult ewes (Al-Obaidi et al., 1987) we obtained indications of an increase in FSH concentration in one flock of PPI $_{1}$-immunized ewes, we were unable to confirm this observation in pubertal ewes in the present study.

A significant advancement of puberty was achieved also in the immunized crossbred ewe lambs in Exp. 1(b), as exemplified by the earlier occurrence of first behavioural oestrus and ovulation. The difference between the control and immunized crossbred lambs was not as obvious as for the Merino lambs because of the earlier puberty seen in most of the control crossbred lambs. Although they were born 1 month earlier in the season than the Merino lambs, the effect of immunization (when the data were examined on a monthly basis) of the crossbred lambs only became significant at 8 months of age (May 1984), when $81 \%$ of the immunized lambs showed oestrus compared with $48 \%$ in the control animals. These findings suggest that up to 3 immunizations are required to advance puberty in ewe lambs. Starting immunization at 3 weeks rather than at 9 weeks of age (Fig. 1) appeared to be more efficacious but this may have been due to the small size of Group $\mathrm{I}_{\mathbf{g}}$.

Ovulation rate was increased by active immunization of young ewe lambs with PPI when repetitive immunization was carried out from 3 or 9 weeks of age (Groups $I_{3}$ and $I_{9}$ of Fig. 1 and Table 1; Group $V_{3}$ of Fig. 2 and Table 2) but not by 3 injections between 3 and 9 weeks of age (Group $V_{9}$ of Fig. 2 and Table 2). This increase was retained for up to 1 year after injections ceased in the Merino lambs. This long-lasting effect, compared to that seen in adults (Cummins et al., 1986), was probably due to the large number of immunizations (O'Shea et al., 1984), rather than the greater purity of the immunogen. Because immunization during 3-9 weeks of age advanced onset of oestrus but was not important for increased ovulation rate, these effects may be mediated by different 
mechanisms. The FSH and $\mathrm{LH}$ data provide no evidence of the involvement of inhibin as neither was altered in the immunized lambs. More frequent gonadotrophin measurements may be necessary to identify subtle effects of immunization treatments on FSH or LH secretion. As in the oestrous cycle of the adult ewe (McNatty et al., 1985), FSH concentrations may need to be elevated only for a relatively short time to advance puberty or increase ovulation rate.

No effect of immunization on advancement of puberty in immunized young rams was evident in this study. This may be due to the observations starting too late and not being frequent enough to reveal changes in testicular morphology and the first appearance of spermatozoa in the ejaculates (Schanbacher et al., 1974; Lee et al., 1976a).

Our immunization treatments increased daily sperm production of adult rams examined during the non-breeding season (i.e. Group $\mathrm{I}_{3}$ vs Group C, August 1984, Table 3; and Group $\mathrm{V}_{3}$ vs Group C, September 1985). This effect may be related to the periodic increases in plasma FSH concentrations seen in the PPI-immunized males (Figs 3 and 4). There are no definitive experiments to support this idea, but the converse is certainly true, i.e. treatment of prepubertal or adult rams with anti-FSH antibodies leads to reduced sperm production (Kilgour et al., 1984; Courot et al., 1984).

It has been reported by Lee et al. (1976b) that around 8 weeks of age there is a relative fall in FSH secretion concurrent with histological changes in the Sertoli cells which may reflect the initial secretion of a non-steroidal FSH inhibiting factor (inhibin) produced by these cells. In the present study falls in FSH concentration were observed in all groups of ram lambs after this age. In the Merino ram lambs immunized from 3 weeks of age the concentration of FSH at 7 weeks of age (i.e. the first measurement) was significantly higher than in the controls. This may reflect the mechanism postulated that immunization causes development of antibodies which modify inhibin feedback from the Sertoli cells on FSH secretion.

The secular changes seen in plasma LH concentrations in the ram were similar to those described in the literature (Cotta et al., 1975; Lee et al., 1976a). The lack of effect of immunization on LH is what would be expected if the action on sperm production were operative through inhibin.

The anomaly in the present experiments is that, in the female, immunization with PPI had a relatively large effect on ovarian function with no demonstrable effect on FSH or LH secretion. In the male, consistent increases in FSH were observed in both experiments but only transient effects on spermatogenesis were seen. Despite this the results suggest that immunization of immature sheep with inhibin or other protein hormones found in follicular fluid could lead to novel methods for manipulating reproduction in sheep.

We thank NIADDK (NIH, Bethesda, MD, U.S.A.) for the LH and FSH radioimmunoassay kits; Dr R. I. Cox (CSIRO, Prospect, Australia) for the progesterone antibody; and Mr J. Sheedy and $\mathrm{Mr}$ R. Nethery for technical assistance. These studies were supported by a grant from the Australian Research Grants Scheme.

\section{References}

Al-Obaidi, S.A.R., Bindon, B.M., Hillard, M.A., O'Shea, T. \& Piper, L.R. (1986) Suppression of ovine plasma FSH by bovine follicular fluid: neutralization by plasma from ewes immunized against an inhibinenriched preparation from bovine follicular fluid. $J$. Endocr. 111, 1-5.

Al-Obaidi, S.A.R., Bindon, B.M., Findlay, J.K., Hillard, M.A. \& O'Shea, T. (1987) Plasma follicle stimulating hormone in Merino ewes immunized with an inhibinenriched fraction from bovine follicular fluid. Anim. Reprod. Sci. 14, (in press).
Avenell, J.A., Saepudin, Y. \& Fletcher, I.C. (1985) Concentrations of LH, oestradiol-17 $\beta$ and progesterone in peripheral plasma of swamp buffalo cows (Bubalus bubalis) around the time of oestrus. J. Reprod. Fert. 74, 419.424 .

Bindon, B.M., Piper, L.R. \& Evans, R. (1982) Reproductive biology of the Booroola Merino. In The Booroola Merino, pp. 21-33. Eds L. R. Piper, B. M. Bindon \& R. D. Nethery. CSIRO, Melbourne.

Blanc, M.R. (1980) L'inhibine. Reprod. Nutr. Develop. 20, $573-586$. 
Cotta, Y., Terqui, M., Pelletier, J. \& Courot, M. (1975) Testosterone et LH plasmatiques chez l'agneau de la naissance a la puberte. C. r. hebd. Séanc. Acad. Sci. Paris D 280, 1473-1476.

Courot, M., Hochereau-de Reviers, M.T., Pisselet, C., Kilgour, R.J., Dubois, M.P. \& Sairam, M.R. (1984) Effect of passive immunization against ovine $\beta$-FSH on spermatogenesis in the ram. In The Male in Farm Animal Reproduction, pp. 75-79. Ed. M. Courot. Martinus Nijhoff, Dordrecht.

Cummins, L.J. (1983) Ovarian function in the Booroola Merino: The role of ovarian inhibiting factors in the regulation of ovulation rate. $\mathrm{Ph} . \mathrm{D}$. thesis, University of New England, Armidale.

Cummins, L.J., O'Shea, T., Bindon, B.M., Lee, V.W.K. \& Findlay, J.K. (1983) Ovarian inhibin content and sensitivity to inhibin in Booroola and control strain Merino ewes. J. Reprod. Fert. 67, 1-7.

Cummins, L.J., O'Shea, T., Al-Obaidi, S.A.R., Bindon, B.M. \& Findlay, J.K. (1986) Increase in ovulation rate after immunization of Merino ewes with a fraction of bovine follicular fluid containing inhibin activity. $J$. Reprod. Fert. 77, 365-372.

Davies, R.V., Main, S.J. \& Setchell, B.P. (1978) Inhibin: Evidence for its existence, methods of bioassay and nature of the active material. Int. J. Androl., Suppl. 2, $102-114$.

de Jong, F.H. (1979) Inhibin-fact or artifact. Molec. cell. Endocr. 13, 1-10.

de Jong, F.H. \& Sharpe, R.M. (1976) Evidence for inhibin like activity in bovine follicular fluid. Nature, Lond. 263, 71-72.

de Jong, F.H., Jansen, E.H.J.M., Hermans, W.P. \& van der Molen, H.J. (1981) Purification, characterization, and in vitro production of inhibin. In Intraovarian Control Mechanisms, pp. 227-250. Eds C. P. Channing \& S. J. Segal. Plenum Press, New York.

Dick, A.T. \& Mules, M.W. (1954) Equipment for the clean collection of twenty-four-hour samples of urine and faeces from sheep. Aust. J. agric. Res. 5, 345-348.

Franchimont, P., Verstraelen-Proyard, J., HazeeHagelstein, M.T., Renard, Ch., Demoulin, A., Bouguignon, J.P. \& Hustin, J. (1979) Inhibin: from concept to reality. Vitams Horm. 37, 243-302.

Henderson, K.M., Franchimont, P., Lecomte-Yerna, M.J., Hudson, N. \& Ball, K. (1984) Increase in ovulation rate after active immunization of sheep with inhibin partially purified from bovine follicular fluid. $J$. Endocr. 102, 305-309.

Hermans, W.P., van Leeuwen, E.C.M., Debets, M.H.M. \& de Jong, F.H. (1980) Involvement of inhibin in the regulation of follicle stimulating hormone concentration in prepubertal and adult, male and female rats. J. Endocr. 86, 79-92.
Jansen, E.H.J.M., Steenbergen, J., de Jong, F.H. \& van der Molen, H.J. (1981) The use of affinity matrices in the purification of inhibin from bovine follicular fluid. Molec. cell. Endocr. 21, 109-117.

Kilgour, R.J., Pisselet, C., Dubois, M.P., Courot, M. \& Sairam, M.R. (1984) The role of FSH in the establishment of spermatogenesis in the lamb. Proc. 10th Int. Congr. Anim. Reprod. \& A. I., Urbana-Champaign II, 52, Abstr.

Lee, V.W.K., Cumming, I.A., de Kretser, D.M., Findlay, J.K., Hudson, B. \& Keogh, E.J. (1976a) Regulation of gonadotrophin secretion in rams from birth to sexual maturity. I. Plasma LH, FSH and testosterone levels. J. Reprod. Fert. 46, 1-6.

Lee, V.W.K., Cumming, I.A., de Kretser, D.M., Findlay, J.K., Hudson, B. \& Keogh, E.J. (1976b) Regulation of gonadotrophin secretion in rams from birth to sexual maturity. II. Response of the pituitary-testicular axis to LH-RH infusion. J. Reprod. Fert. 46, 7-11.

Lino, B.F., Braden, A.W.H. \& Turnbull, K.E. (1967) Fate of unejaculated spermatozoa. Nature, Lond. 213, $594-595$.

McNatty, K.P., Hudson, N., Gibb, M., Ball, K., Henderson, K.M., Heath, D.A., Lun, S. \& Kieboom, L.E. (1985) FSH influences follicle viability, oestradiol biosynthesis and ovulation rate in Romney ewes. $J$. Reprod. Fert. 75, 121-131.

O'Shea, T., Al-Obaidi, S.A.R., Bindon, B.M., Cummins, L.J., Findlay, J.K. \& Hillard, M.A. (1984) Increased ovulation rate in Merino ewes and advancement of puberty in Merino lambs immunized with a preparation enriched in inhibin. In Reproduction in Sheep, pp. 335-337. Eds D. R. Lindsay \& D. T. Pearce. Australian Academy of Science, Canberra.

Robertson, D.M., Foulds, L.M., Leversha, L., Morgan, F.J., Hearn, M.T.W., Burger, H.G., Wettenhall, R.E.H. \& de Kretser, D.M. (1985) Isolation of inhibin from bovine follicular fluid. Biochem. Biophys. Res. Commun. 126, 220-226.

Schanbacher, B.D., Gomes, W.R. \& Van Demark, N.L. (1974) Developmental changes in spermatogenesis, testicular carnitine acetyltransferase activity and serum testosterone in the ram. J. Anim. Sci. 39, 889-892.

Vijayalakshmi, S., Bandivdekar, A.H., Joshi, L.R., Moodbidri, S.B. \& Sheth, A.R. (1980) Isolation and characterization of ovine testicular and ovarian inhibin. Archs Androl. 5, 179-188. 